MATEC Web of Conferences 15, 01020 (2014)

DOI: $10.1051 /$ matecconf/ 20141501020

(C) Owned by the authors, published by EDP Sciences, 2014

\title{
Axial Compressive Strength of Foamcrete with Different Profiles and Dimensions
}

\author{
M.A. Othuman Mydin ${ }^{1}$, M.A.S. $\operatorname{Sudin}^{2}$, N. Md Sani ${ }^{3}$ \\ ${ }^{1,2,3}$ School of Housing, Building and Planning, Universiti Sains Malaysia, 11800 Penang, Malaysia
}

\begin{abstract}
Lightweight foamcrete is a versatile material; primarily consist of a cement based mortar mixed with at least $20 \%$ volume of air. High flow ability, lower self-weight, minimal requirement of aggregate, controlled low strength and good thermal insulation properties are a few characteristics of foamcrete. Its dry densities, typically, is below 1600 $\mathrm{kg} / \mathrm{m}^{3}$ with compressive strengths maximum of $15 \mathrm{MPa}$. The ASTM standard provision specifies a correction factor for concrete strengths of between 14 and $42 \mathrm{MPa}$ to compensate for the reduced strength when the aspect height-to-diameter ratio of specimen is less than 2.0, while the CEB-FIP provision specifically mentions the ratio of $150 \times 300$ $\mathrm{mm}$ cylinder strength to $150 \mathrm{~mm}$ cube strength. However, both provisions requirements do not specifically clarify the applicability and/or modification of the correction factors for the compressive strength of foamcrete. This proposed laboratory work is intended to study the effect of different dimensions and profiles on the axial compressive strength of concrete. Specimens of various dimensions and profiles are cast with square and circular cross-sections i.e., cubes, prisms and cylinders, and to investigate their behavior in compression strength at 7 and 28 days. Hypothetically, compressive strength will decrease with the increase of concrete specimen dimension and concrete specimen with cube profile would yield comparable compressive strength to cylinder $(100 \times 100 \times 100 \mathrm{~mm}$ cube to 100 dia $\times 200 \mathrm{~mm}$ cylinder).
\end{abstract}

\section{Introduction}

The differences between the types of lightweight concrete are particularly related to its aggregate grading used in the mixes. Foamcrete is a type of porous concrete and by referring to its features and use, it is quiet similar to aerated concrete [1]. The synonyms for foamcrete are: aerated concrete, lightweight concrete or porous concrete. Foamcrete is a versatile material; primarily consist of a cement based mortar mixed with at least $20 \%$ volume of air [2]. High flow ability, lower selfweight, minimal requirement of aggregate, controlled low strength and good thermal insulation properties were few characteristics of it [3]. Its dry densities, typically, does below $1600 \mathrm{~kg} / \mathrm{m}^{3}$ with compressive strengths maximum of $15 \mathrm{Mpa}$ [4]. Typically, foamcrete does not contain coarse aggregate, and is formed by introducing air or other gas into a cement slurry and fine sand [5]. In industrial practice, pulverized fuel ash or other siliceous material is used to replaced the sand, and instead of cement, lime used as the replacement [6].

Foamcrete produced by the mixing of ordinary portland cement (OPC), sand and/or alone fly ash, water and preformed stable foam. The foam is generated with the help of a foam generator, using foaming solution with 1:30 ratio to water. The air/foam content is normally between 40 to 80 percent 
of the total volume. Foamcrete is different compared to, (a) gas/aerated concrete, where the foam are chemically formed through the reaction of aluminium powder with calcium hydro oxide and other alkalizes released by cement hydration and, (b) air entrained concrete, which a much lower volume of entrained air is used in concrete for durability. Foamcrete curing may be done as per IS: 456-2000 and can be accelerated by steam. Foamcrete may be produced by mixing the above mentioned ingredients in ready mix plant or ordinary concrete mixer [7]. Foamcrete is a self compacting concrete (requires no compaction) and will flow readily from a pump outlet to fill mould, formwork, restricted and/or irregular cavities. It can be pumped effectively over reasonable heights and distances. The 28 days compressive strength and dry density of the material vary accordingly to its composition and usually depends on mixture air voids content. The target plastic or wet density during mixture is usually about 150 to $200 \mathrm{~kg} / \mathrm{m}^{3}$ higher than the dry density [8].

There are two methods used to prepare the aerated/foamcrete. The first method is by injecting the gas into the mixing during its plastic condition by means of a chemical reaction and the second one is by introducing the air, either by mixing-in stable foam or by whipping-in air, using an air-entraining agent [9]. The first method is usually used in precast concrete factories where the precast units are subsequently autoclaved in order to produce concrete with a reasonable high strength and low drying shrinkage [10]. The second method is generally used for in-situ concrete which is suitable for pipe lagging or insulation roof screeds. At present, there are no regulations or standard methods for proportioning foamcrete because the hardened density of foamcrete depends on the saturation level in its pores [11]. However, certain mix proportions by real trials might worked out with the given set of site materials for requisite compressive strength, plastic density and workability $[12,13]$. Usually the OPC cement of foamcrete lies between 300 to $500 \mathrm{~kg} / \mathrm{m}^{3}$ and with, between 0.4 to 0.8 , W/C or $\mathrm{W} / \mathrm{C}+\mathrm{FA}$ ratio including the water in foam value. The higher values are required with finer grained binders such as fly ash. Basically, compressive strength capability of a material or structure to resist axially directed pushing forces - is the main measurement of quality of concrete in structural design is its compressive strength [14,15]. Concrete with brittle materials are crushed when the limit of compressive strength is reached. So, by definition, the compressive strength of a material is that value of axial compressive stress obtained when the material fails completely [16,17].

\section{Literature Review}

It was found that compressive strength is not reliant on the specimen size but it was observed when the strength level increases standard deviations also increase. The highest clear strengths were obtained for 100 dia $\times 200 \mathrm{~mm}$ cylinder and $150 \mathrm{~mm}^{3}$ cube specimens. Specimens smaller and larger than $100 \times 200 \mathrm{~mm}$ cylinder and $150 \mathrm{~mm}^{3}$ cube specimens had lower strength.

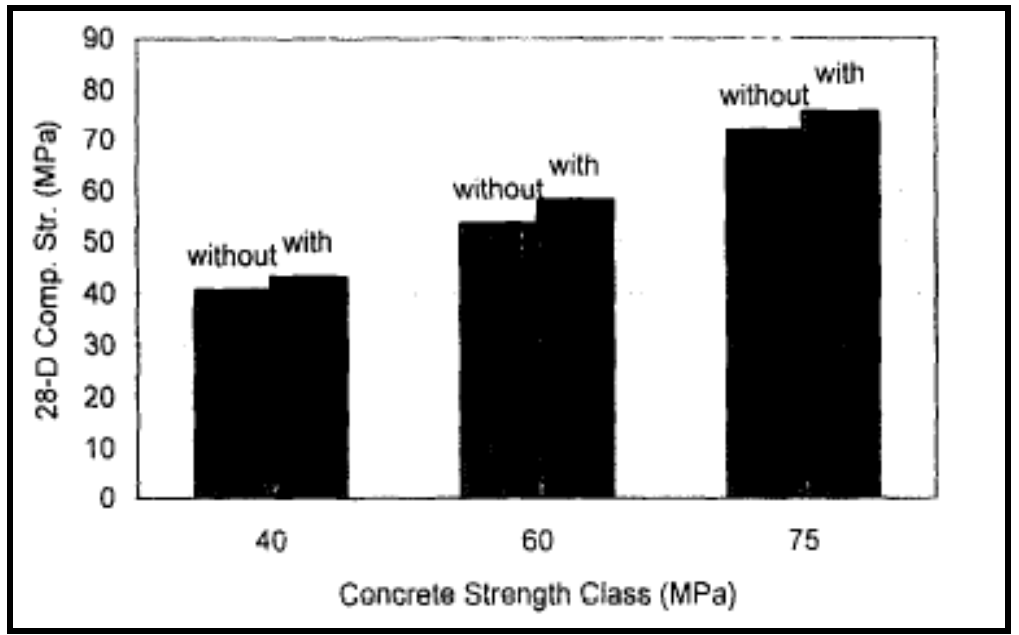

Figure 1: Strength comparison of $75 \times 150 \mathrm{~mm}$ cylinder specimens with and without additional mortar [6] 


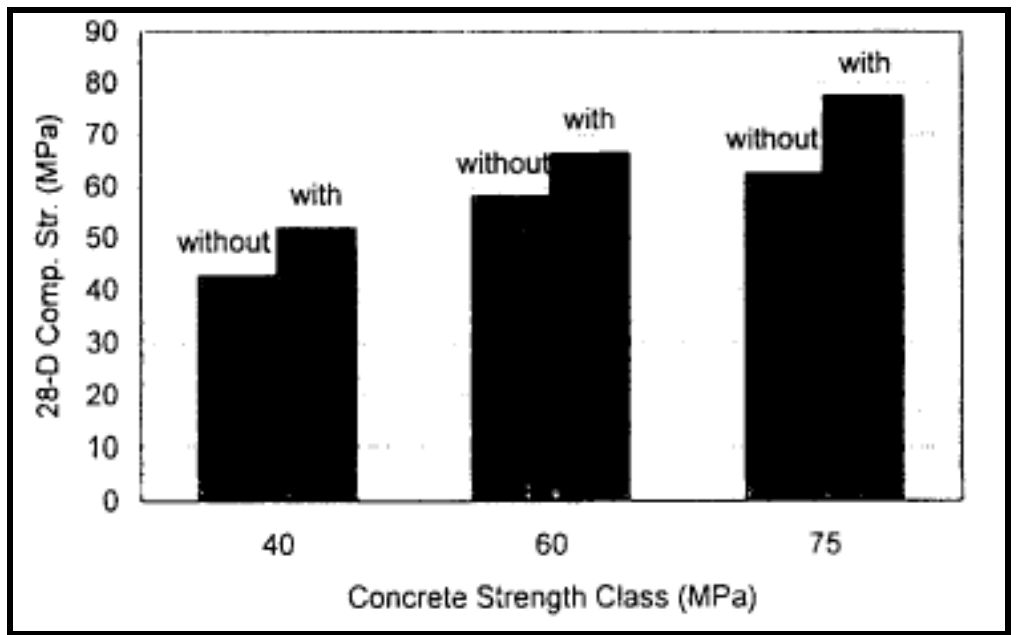

Figure 2: Strength comparison of $75 \mathrm{~mm}$ cube specimens with and without additional mortar [6]

Consequently, the measured strength of the specimen decreases with increase in its size. Then again, with the same reasoning, the smaller specimens should have higher apparent strengths. The agreement for smaller specimens was attributed to the "wall effect". The amount of mortar required to fill the space between the particles of the coarse aggregate and the wall of the mould is larger than that required in the interior of the mass, therefore in surplus of the mortar available even in a wellproportioned mix [8]. High strength concretes are less affected by changes in 1/d ratio. From Fig. 1, $10 \%$ increase in the mortar content resulted in $6.28,8.63$, and $5.01 \%$ increase in the strength of $75 \mathrm{x}$ $150 \mathrm{~mm}$ cylinder specimens for the 40,60 , and $75 \mathrm{MPa}$ strength levels.

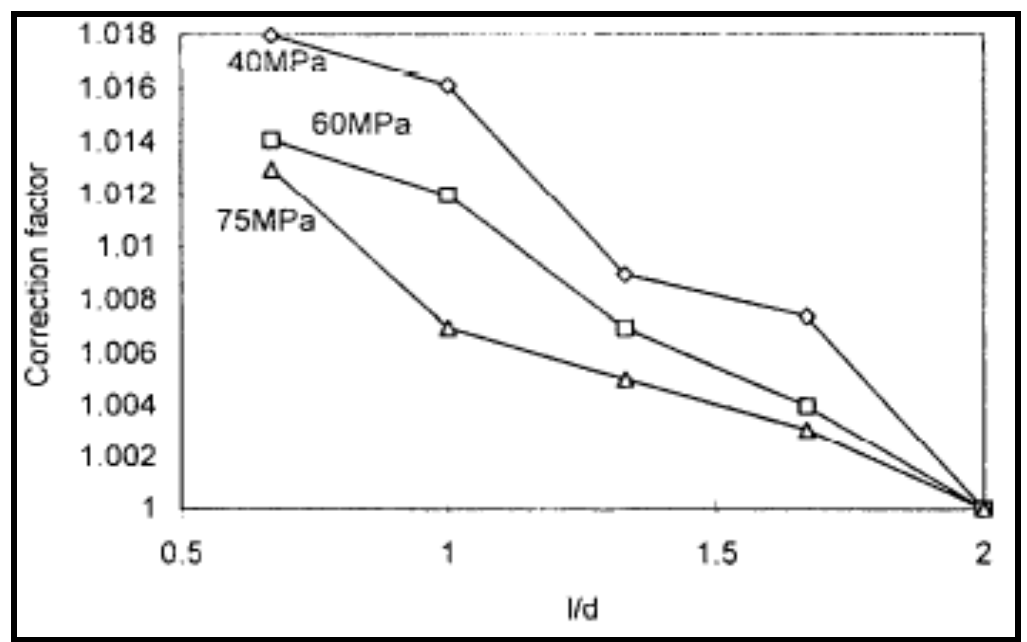

Figure 3: Strength test results of cylinders with different $1 / \mathrm{d}[6$

In Fig. 2, the strengths of $75 \mathrm{~mm}$ cubes with increased mortar were $21.45,14.04$, and $24.18 \%$ higher than those of the original specimens and found to be applicable according to the results of the present study too, as shown in Fig. 3. There is a great disparity between the correction factors obtained in this investigation and those given by ASTM C 42. Then again, they are related in the sense that they can both be described by power equations as shown in Fig. 4. 


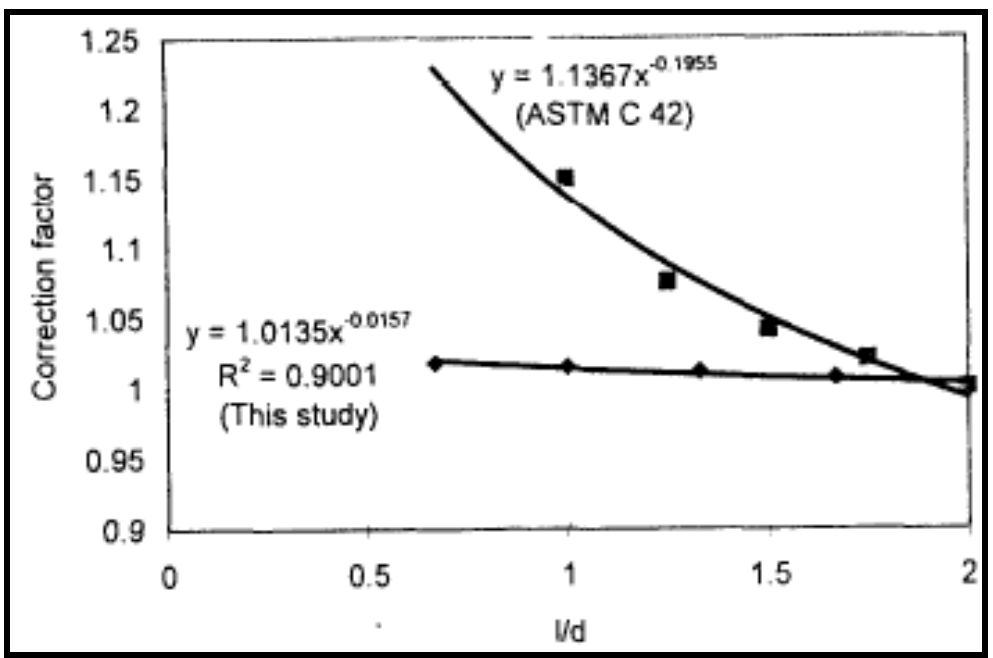

Figure 4: Comparison of correction factors obtained in this investigation with those given in ASTM C 42 [6]

\section{Experimental Works}

Material and mix design: Foamcrete mixes, with target dry density of $1250 \mathrm{~kg} / \mathrm{m}^{3}$, were prepared containing Ordinary Portland Cement (OPC), sand as fine aggregate, water and stable foamed. Three batches of mixes were done for three types of samples with various dimensions and profiles. Three samples type from three mixes; (a) different specimen profiles (cube, prism and cylinder) with 1/d of 1.0 and 2.0, (b) same dimension specimens with different profiles, and (c) cube specimen with $1 / \mathrm{d}=$ 1.0 but different section dimensions. Fig. 5 shows the foam generator used to generate stable foam.

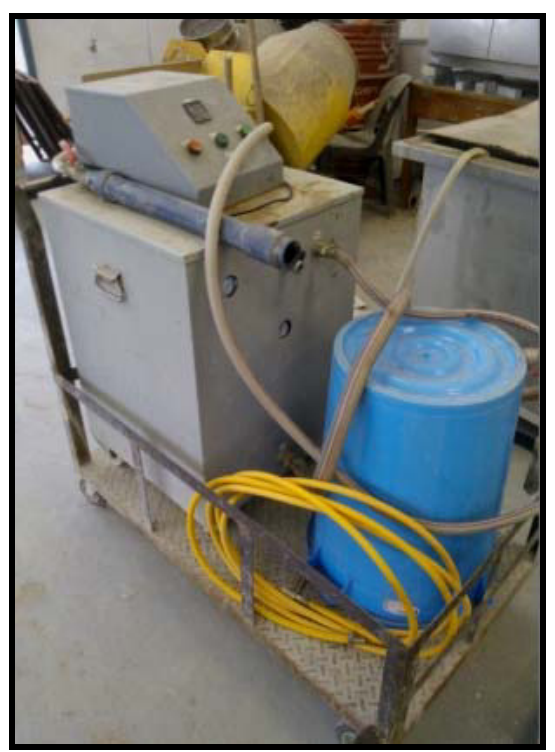

Figure 5: Foam Generator type TM-1

\subsection{Curing}

All cylinder and cube samples were wrapped in an air-tight condition with plastic sheet after demould, for curing. Samples unwrapped, on day 6 (7 day testing) and on day 27 (28 day testing) for another 24-hours oven dry curing $\left(100-110^{\circ} \mathrm{C}\right)$ before testing (Fig. 6). 


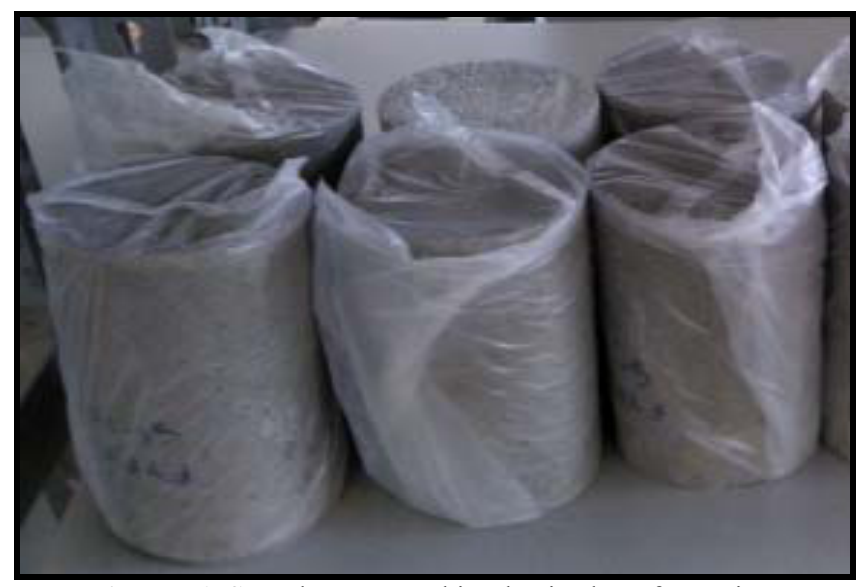

Figure. 6: Samples wrapped in plastic sheet for curing.

\subsection{Method of Testing}

The compression test procedure was done with accordance to MS 26: part 2: 1991. Testing was conducted using GOTECH GT-7001-BS300, a closed-loop servo-hydraulic dynamic with 300 tancapacity compression machine. Loading rate was adjusted for all specimens to be $0.2-0.4 \mathrm{~N} / \mathrm{mm}^{2} \mathrm{~s}$. The spherical bearing block height of the test machine was changed depending on the height of the tested specimens.

\subsection{Results and Discussions}

Table 1 shows the complete results for samples A, B and C. As been shown in Table 2, there is $16.4 \%$ compression strength reduction when $1 / \mathrm{d}$ ratio of cube and prism increase from 1.0 to 2.0 , but for cylinder, the strength became $15.4 \%$ higher for the same $1 / \mathrm{d}$ ratio change. By referring to CEB-FIP standard of comparison, when $100 \times 100 \times 100 \mathrm{~mm}$ cube $(1 / \mathrm{d}=1.0)$ compared to $100 \mathrm{dia} \times 100 \mathrm{~mm}$ cylinder $(1 / \mathrm{d}=2.0)$, there is only $5 \%$ difference in compressive strength, which, could be treat as margin of error during samples preparation, curing or testing. By reducing the effective crosssectional area differences between cube (prism) and cylinder during testing, data comparison can be centred more on the effects of specimen's profile to its compressive strength.

Table 1. Experiment results for samples A, B and C at 28 days test

\begin{tabular}{|c|c|c|c|c|c|}
\hline Profile & Section, $\mathrm{mm}$ & Height, mm & $\begin{array}{c}\text { Dry density, } \\
\mathrm{kg} / \mathrm{m}^{3}\end{array}$ & Max load, kN & $\begin{array}{c}\text { Compressive } \\
\text { strength, } \mathrm{kN} / \mathrm{mm}^{2}\end{array}$ \\
\hline \multicolumn{6}{|c|}{ Sample A } \\
\hline Cube & \multirow{2}{*}{$100 \times 100$} & 100 & 1200 & 43.94 & 4.39 \\
\hline Prism & & 200 & 1189 & 36.68 & 3.67 \\
\hline \multirow{2}{*}{ Cylinder } & \multirow{2}{*}{100 (diameter) } & 100 & 1223 & 30.64 & 3.90 \\
\hline & & 200 & 1267 & 36.22 & 4.61 \\
\hline \multicolumn{6}{|c|}{ Sample B } \\
\hline Cube & \multirow{2}{*}{$40 \times 40$} & 50 & 1173 & 7.82 & 4.89 \\
\hline Prism & & 100 & 1230 & 8.00 & 5.00 \\
\hline \multirow{2}{*}{ Cylinder } & 43.0 (diameter) & 50 & 1190 & 6.80 & 4.68 \\
\hline & 43.4 (diameter) & 100 & 1187 & 7.56 & 5.11 \\
\hline \multicolumn{6}{|c|}{ Sample C } \\
\hline \multirow{3}{*}{ Cube } & $50 \times 50$ & 50 & 1216 & 8.38 & 3.35 \\
\hline & $100 \times 100$ & 100 & 1209 & 40.01 & 4.00 \\
\hline & $150 \times 150$ & 150 & 1179 & 78.89 & 3.51 \\
\hline
\end{tabular}


The initial target cross-sectional area for cylinder is $45 \mathrm{~mm}$ diameter $\left(1590 \mathrm{~mm}^{2}\right)$ to compare with $40 \times 40 \mathrm{~mm}\left(1600 \mathrm{~mm}^{2}\right)$ cube. But, because of the frictional loss of surface area during curing process of $100 \times 100 \times 500 \mathrm{~mm}$ prism to obtained $45 \mathrm{dia}$. $\times 50 \mathrm{~mm}$ and $100 \mathrm{~mm}$ cylinder, effective crosssectional cylinder tested have become the average of $43.5 \mathrm{~mm}\left(1486 \mathrm{~mm}^{2}\right)$. Nonetheless, as we can see from Table 3, cube (and prism) could handle higher loading than cylinder by $13.0 \%$ if both depth is $50 \mathrm{~mm}$ but the advantage reduce to $5.5 \%$ when depth up to $100 \mathrm{~mm}$.

Table 2. Compressive strength comparison between samples A

\begin{tabular}{|c|c|c|c|c|}
\hline Sample A & Cube & Prism & Cylinder, $\mathrm{d}=100 \mathrm{~mm}$ & Cylinder, $\mathrm{d}=200 \mathrm{~mm}$ \\
\hline Cube, $\mathrm{d}=100 \mathrm{~mm}$ & & $+16.4 \%$ & $+11.2 \%$ & $-5.0 \%$ \\
\hline Prism, $\mathrm{d}=200 \mathrm{~mm}$ & $-19.6 \%$ & & $-6.3 \%$ & $-25.6 \%$ \\
\hline Cylinder, $\mathrm{d}=100 \mathrm{~mm}$ & $-12.6 \%$ & $+5.9 \%$ & & $-18.2 \%$ \\
\hline Cylinder, $\mathrm{d}=200 \mathrm{~mm}$ & $+4.8 \%$ & $+20.4 \%$ & $+15.4 \%$ & \\
\hline
\end{tabular}

According to research done by Othuman Mydin, compressive strength decrease as sample dimension increase for lightweight aggregate concrete [3]. But, from Table 4, for foamcrete, cube with $100 \mathrm{~mm}^{3}$ has the highest compressive strength from all of the samples. Even $150 \mathrm{~mm}^{3}$ cube produce higher result than $50 \mathrm{~mm}^{3}$. One of the reason might be due to foamcrete mechanical properties of having low compressive strength (maximum $\mathrm{f}_{\mathrm{cu}}$ of $15 \mathrm{MPa}$ ), cube dimension with $50 \mathrm{~mm}^{3}$ parameter are not suitable to be used as specimen in foamcrete compression test.

Table 3. Compressive strength comparison between samples B

\begin{tabular}{|c|c|c|c|c|}
\hline Sample B & Cube & Prism & Cylinder, $\mathrm{d}=50 \mathrm{~mm}$ & Cylinder, $\mathrm{d}=100 \mathrm{~mm}$ \\
\hline Cube, $\mathrm{d}=100 \mathrm{~mm}$ & & & $+4.3 \%$ & $-4.5 \%$ \\
\hline Prism, $\mathrm{d}=200 \mathrm{~mm}$ & & & $+6.4 \%$ & $-2.2 \%$ \\
\hline Cylinder, $\mathrm{d}=50 \mathrm{~mm}$ & $-4.5 \%$ & $-6.8 \%$ & & \\
\hline Cylinder, $\mathrm{d}=100 \mathrm{~mm}$ & $+4.3 \%$ & $+2.2 \%$ & & \\
\hline
\end{tabular}

Table 4. Compressive strength comparison between samples $\mathrm{C}$

\begin{tabular}{|c|c|c|c|}
\hline Sample C & Cube, $50 \mathrm{~mm}^{3}$ & Cube, $100 \mathrm{~mm}^{3}$ & Cube, $150 \mathrm{~mm}^{3}$ \\
\hline Cube, $50 \mathrm{~mm}^{3}$ & & $-19.4 \%$ & $-4.8 \%$ \\
\hline Cube, $100 \mathrm{~mm}^{3}$ & $+16.3 \%$ & & $+12.3 \%$ \\
\hline Cube, $150 \mathrm{~mm}^{3}$ & $+4.6 \%$ & $-14.0 \%$ & \\
\hline
\end{tabular}

\section{Conclusions}

The effects of the dimension and profile (section profile and aspect ratio) of a specimen on the foamcrete compressive strength was examined according to the unit weight of $1250 \mathrm{~kg} / \mathrm{m} 3$. From the experimental results established, the following conclusions may be drawn:

1. Cylinder specimen has less change in compressive strength $\left(f_{c u}\right)$ when $1 / d$ ratio change from 1.0 to 2.0 compared to cube. In fact, $\mathrm{f}_{\mathrm{cu}}$ for cylinder increase as $1 / \mathrm{d}$ increase, whereas for cube, there is $18.2 \%$ reduction in compressive strength.

2. Cube could carry higher load than cylinder (by assuming both cross-section and volume as identical).

3. At same $1 / \mathrm{d}$ ratio and profile (cube only), for foamcrete, $f_{\mathrm{cu}}$ does not decrease as specimen dimension increase.

4. As CEB-FIP provision specified, even for foamcrete, $100 \times 100 \mathrm{~mm}$ cube $(1 / \mathrm{d}=1.0)$ does produced comparable compressive strength with 100dia. $x 200 \mathrm{~mm}$ cylinder $(1 / \mathrm{d}=2.0)$. 


\section{Acknowledgement}

The authors would like to thank Universiti Sains Malaysia for their support under USM Short Term Grant (203/PPBGN/6312147).

\section{References}

1. Strokova, V.V., A.V. Cherevatova, 2013. Prospects of Application of Zero-Cement Binders of a Nonhydration Hardening Type, World Applied Sciences Journal 25 (1): 119-123

2. Roslan, A.H., H. Awang, M.A. Othuman Mydin, 2013. Effects of Various Additives on Drying Shrinkage, Compressive and Flexural Strength of Lightweight Foamed Concrete (LFC). Advanced Materials Research Journal, 626: 594-604

3. Othuman Mydin, M.A., 2013. Modeling of Transient Heat Transfer in Foamed Concrete Slab. Journal of Engineering Science and Technology, 8 (3): 331-349

4. Herki, B.A., J.M. Khatib, E.M. Negim, 2013. Lightweight Concrete Made from Waste Polystyrene and Fly Ash. World Applied Sciences Journal, 21 (9): 1356-1360

5. Othuman Mydin, M.A., Y.C. Wang, 2012. Thermal and mechanical properties of Lightweight Foamed Concrete (LFC) at elevated temperatures. Magazine of Concrete Research, 64 (3): 213224

6. Aldridge, D., T. Ansell, 2001. Foamed Concrete: Production and Equipment Design, Properties, Applications and Potential. In: Proceedings of one day seminar on foamed concrete: Properties, applications and latest technological developments, Loughborough University

7. Othuman Mydin, M.A., Y.C. Wang, 2011. Elevated-Temperature Thermal Properties of Lightweight Foamed Concrete. Journal of Construction \& Building Materials, 25 (2): 705-716

8. Khatib, J.M., S. Shariff, E.M. Negim, 2012. Effect of Incorporating Foamed Glass on the Flexural Behaviour of Reinforced Concrete Beams, World Applied Sciences Journal 19 (1): 47-51

9. Norgaard, J., M.A. Othuman Mydin, 2013. Drywall Thermal Properties Exposed to High Temperatures and Fire Condition. Jurnal Teknologi, 62 (1): 63-68

10. Othuman Mydin, M.A., 2013. An Experimental Investigation on Thermal Conductivity of Lightweight Foamcrete for Thermal Insulation. Jurnal Teknologi, 63 (1): $43-49$

11. Awang, H., M.A. Othuman Mydin, A.F. Roslan, 2012. Effects of Fibre on Drying Shrinkage, Compressive and Flextural Strength of Lightweight Foamed Concrete. Advanced Materials Research, Trans Tech Publications, Switzerland, 587: 144-149

12. Othuman Mydin, M.A., Y.C. Wang, 2011. Structural Performance of Lightweight Steel-Foamed Concrete-Steel Composite Walling System under Compression. Journal of Thin-walled Structures, 49 (1): 66-76

13. Awang, H., M.A. Othuman Mydin, A.F. Roslan, 2012. Microstructural investigation of lightweight foamed concrete incorporating various additives. International Journal of Academic Research, 4 (2): 197-201

14. Othuman Mydin, M.A., Y.C. Wang, 2012. Mechanical properties of foamed concrete exposed to high temperatures. Journal of Construction and Building Materials, 26 (1): 638-654

15. Herki, B.A., J.M. Khatib, E.M. Negim, 2013. Lightweight Concrete Made from Waste Polystyrene and Fly Ash. World Applied Sciences Journal, 21 (9): 1356-1360

16. Soleimanzadeh, S., M.A. Othuman Mydin, 2013. Influence of High Temperatures on Flexural Strength of Foamed Concrete Containing Fly Ash and Polypropylene Fiber, International Journal of Engineering, 26 (1): 365-374

17. Othuman Mydin, M.A., 2011. Thin-walled steel enclosed lightweight foamcrete: A novel approach to fabricate sandwich composite. Australian Journal of Basic and Applied Sciences, 5 (12): $1727-1733$ 